\title{
Size, book-to-market, and momentum during the business cycle
}

\author{
Patrick Scheurle $\cdot$ Klaus Spremann
}

Received: 24 June 2009/Accepted: 3 March 2010

(C) Springer-Verlag 2010

\begin{abstract}
The Fama-French-Methodology (1993-1998) offers cross-sectional explanations of returns by taking the specially designed portfolios SMB and HML as additional factors. It is acknowledged that these factors are related to some forms of risk (they bear premia) which, by researchers is often proposed to be related to the uncertainty with respect to macroeconomic production and aggregate consumption. In more recent research a momentum factor is included in order to improve the explanatory power of the Fama-French-Model. We use data from business cycles 1926-2007 to show that SMB represents the risks related to the very early phase of an upswing while HML may be related to the uncertainty whether a business cycle will continue to gain depth and strength (or shifts back into recession). In contrast to SMB and HML, we do not find momentum to be related to risks associated with particular phases of the business cycle.
\end{abstract}

Keywords Fama-French - Small caps - Value stocks · Momentum · Real economy $\cdot$ Business cycle

JEL Classification $\mathrm{G} 11 \cdot \mathrm{G} 12$

We thank two anonymous referees for their valuable comments on earlier versions of this paper.

P. Scheurle · K. Spremann ( $\square)$

Swiss Institute of Banking and Finance, University of St. Gallen,

Rosenbergstrasse 52, 9000 St. Gallen, Switzerland

e-mail: klaus.spremann@unisg.ch

P. Scheurle

e-mail: patrick.scheurle@unisg.ch 


\section{Introduction}

During the past 20 years, empirical research made evident that returns in capital markets are not explained by beta alone, in contrast to the CAPM. Basu (1977, 1983) discovered the value effect: There is a relation between the expected return of a stock and the market-to-book ratio of the firm. Banz (1981), Reinganum (1981), and Roll (1981) found the size effect: The return depends on the size of the firm as measured by the market value of equity ME. To explore these and similar effects, Fama and French (1993) introduced specially designed long short portfolios which express, in a pronounced way, the behavior of groups of stocks for firms with a common feature. The portfolio small minus big (SMB) is long in stocks of small and short in stocks of large firms. SMB gives a sharp and amplified picture of the behavior of small caps (in contrast to large firms). high minus low (HML) is long in stocks of firms with a high book-to-market ratio (value stocks) and short in firms having a low book-to-market ratio (glamour and growth stocks). So, HML gives a clear-cut picture of the behavior of value stocks.

The Fama-French-Methodology explains the risk premium $P_{k, t}$ of asset $k$ in period $\mathrm{t}$ by three factors $\mathrm{MKT}_{t}, \mathrm{SMB}_{t}$ and $\mathrm{HML}_{t}$. The first factor MKT is the excess return of the market portfolio as known from the single-index model (Sharpe 1963). The other two factors extend this basic model:

$$
P_{k, t}=a_{k}+b_{k} \cdot \mathrm{MKT}_{t}+c_{k} \cdot \mathrm{SMB}_{t}+d_{k} \cdot \mathrm{HML}_{t}+\varepsilon_{t}
$$

Hence, the excess return of an asset $k$ in period $t$ does not only depend on the excess return of the market portfolio in the same period and the exposure ("beta") asset $k$ shows with respect to the market. The excess return of asset $k$ is additionally explained by the behavior of small and value stocks in period $t$ as described by the returns of the two long short portfolios.

Like the return on the market portfolio, the two additional factors are "systematic". Their randomness can hardly be diversified, and they are associated with a risk premium. The expected return of SMB is $0.27 \%$ per month or more than $3 \%$ per year (size effect); the expected return of HML is $0.40 \%$ on a monthly and almost $5 \%$ on a yearly basis (value effect), see Fama and French (1993). While these figures refer to US data, premia of similar magnitude have been found for the capital markets of other countries. ${ }^{1}$ Moreover, Griffin (2002) provides evidence on the superior performance of domestic risk factors over global risk factors.

Although the premia are well established, not so much is known about the nature of the riskiness these factors SMB and HML represent. Fama and French speak of "changing investment opportunities" which have an impact on returns. Other researchers, such as Amihud (2002) see the premia as compensations for adverse properties of the underlying groups of stocks. Here, several unwanted aspects have been proposed as an explanation. For instance, Amihud (2002) finds that small caps are more affected by illiquidity than large caps. Thus, an asset $k$ which behaves to some degree like small firms ( $c_{k}$ being above average) should compensate investors

\footnotetext{
${ }^{1}$ Cf. for instance, Fama and French (1998). In addition, Fama and French (2006) show international results for the value premium among size-sorted portfolios.
} 
for the disadvantages of small stocks. Other research proposes that particular groups of stocks are specially suffering in a recession or in a crisis (Rietz (1988), Barro (2005)). ${ }^{2}$ Chen and Zhang (1998) relate the high returns of value stocks to risks arising from distress or high financial leverage.

Despite these considerations did not lead to a single conclusion, most researchers link the factors SMB and HML to the risk associated with the real economy, production growth and aggregate consumption. This view is supported by theoretical considerations (Cochrane 1999). Most investors have an exposure in the business cycle since their income is derived from activity in the real economy. In order not to magnify this exposure and, as a consequence, to lose both income and financial wealth in a recession, the majority of investors avoids assets which have strong "betas" with respect to the real economy. The corresponding securities are cheap and offer a higher return.

A few pieces of research support this proposition of a relation between SMB and HML on the one hand and the real economy on the other. Empirical work by Chen et al. (1986) suggests that uncertainty related to the growth rate of industrial production is associated with a risk premium. ${ }^{3}$ Liew und Vassalou (2000) show that SMB and HML are associated with the development of the GDP. Their empirical evidence may indicate the mimicking role of SMB and HML for the real economy. In addition, Perez-Quiros and Timmermann (2000) find that small caps are more affected by tightening credit markets than large caps. As credit markets tend to tighten during economic downturns, we interpret this as further evidence on a relationship between the real economy and the return differential of small caps and large caps. So far, however, there is no evidence giving a precise picture of the relation between the two long-short portfolios and particular phases of the business cycle. Moreover, it is an open question why both portfolios SMB and HML contribute to better explain cross-sectional returns.

In addition, more recent research like Carhart (1997) extends the Fama-FrenchModel by including another long-short portfolio, often referred to as up-minusdown (UMD) or winners-minus-losers (WML). This factor captures the so-called momentum effect, i.e. the puzzling anomaly first observed by Jegadeesh and Titman (1993) that past winners continue to outperform past losers. Although there is a broad body of research documenting the momentum effect, a sound theoretical foundation still seems unreached.

Put in a nutshell, this paper aims to provide evidence on the relationship between the risk premia of the factor-mimicking portfolios SMB, HML, as well as a momentum factor MOM and the different phases of the real economy. We show that SMB may represent the risk during the beginning of a new business cycle, while HML might account for the uncertainty in the next phase, when, after the early beginning, economic activity could either deepen and continue to grow or fall back into recession. In contrast to SMB and HML, we do not find momentum to mimic for risks associated to the business cycle.

\footnotetext{
2 Mehra and Prescott (1988) challenge some assumptions and the approach outlined by Rietz (1988).

3 Bessler and Opfer (2003) provide evidence on risk premia associated with macroeconomic variables for the German stock market.
} 
Table 1 Business cycle details (source: NBER)

\begin{tabular}{lr}
\hline 1926-2007 & 15 \\
\hline Number of peaks & 14 \\
Number of troughs & 57 \\
Average duration of expansions (months) & 13 \\
Average duration of contractions (months) & 12 \\
Shortest expansion (months) & 120 \\
Longest expansion (months) & 6 \\
Shortest contraction (months) & 43 \\
Longest contraction (months) &
\end{tabular}

\section{Conditional returns of SMB, HML, and MOM}

The business cycle is usually indicated by the level and the growth rate of GDP. We use data from the national bureau of economic research (NBER) which includes data from the labor market to define the level of aggregate activity. Each cycle contains a peak and bottom, which are defined by the turning points of growth rates. ${ }^{4}$ We choose the time window from 1926 till 2007, the year of the last turn in the business cycle according the NBER. As shown in Table 1, there had been 15 peaks and 14 troughs during $1926-2007 .^{5}$

In order to cope with the variation in the length of business cycles, we focus on returns in the single months before and after the (months which contain the) turning points. We determine the average returns, based on the data provided by the online database of Kenneth French, of portfolios like SMB, HML, and MOM for each of these months, where the averages are taken over all business cycles. ${ }^{6}$ These average returns are also seen as estimates of expected returns conditional to the phase during the cycle. We compare these conditional expected returns of the various portfolios and check their levels of significance. Beneath SMB, HML, and MOM we look at the Market Index MKT and determine the returns for the portfolios SH, SM, SL, $\mathrm{BH}, \mathrm{BM}$ and $\mathrm{BL}$ which constitute SMB and HML. In the Fama-FrenchMethodology, the portfolios $\mathrm{SH}, \ldots, \mathrm{BL}$ are constructed by double ranking according to size (market value of equity) and book-to-market. Thus, SH contains stocks of smaller companies with a high book-to-market ratio. BL is composed of stocks of

\footnotetext{
${ }^{4}$ Usually, the "two-quarter-with negative growth-rates rule" also holds for NBER-recessions.

5 The need to use data from the real economy leads to study the US economy. A typical business cycle is 70 months long, such that long time series are required in order to cover a sufficient number of cycles. The NBER in the US offers a documentation of cycles back to the 19th century. The NBER also reports the peaks and troughs. The financial returns are taken from the data bank provided by Kenneth French, which offers the returns of the six Portfolios SH,...,BL as well as for MKT, SMB, HML, and MOM. These time series cover the months beginning from 1926.

${ }^{6}$ The financial returns can be downloaded at http://mba.tuck.dartmouth.edu/pages/faculty/ken.french/ data_library.html.
} 
big companies having a low book-to-market ratio. ${ }^{7}$ The returns of these portfolios define the factors SMB and HML:

$$
\begin{gathered}
\mathrm{SMB}_{t}=\frac{1}{3} \cdot\left(\mathrm{SH}_{t}+\mathrm{SM}_{t}+\mathrm{SL}_{t}\right)-\frac{1}{3} \cdot\left(\mathrm{BH}_{t}+\mathrm{BM}_{t}+\mathrm{BL}_{t}\right) \\
\mathrm{HML}_{t}=\frac{1}{2} \cdot\left(\mathrm{SH}_{t}+\mathrm{BH}_{t}\right)-\frac{1}{2} \cdot\left(\mathrm{SL}_{t}+\mathrm{BL}_{t}\right)
\end{gathered}
$$

There is no unique way in order to determine momentum returns. However, as with SMB and HML, MOM represents returns of a long-short portfolio. In general, momentum returns are represented by the return differential between winner stocks and loser stocks. The classification into the groups winners and losers is usually based on past returns of the most recent 6-12 months. This means that the constituents of the winner-portfolio $W$ at $t$ and the loser-portfolio $L$ at $t$ are determined by the past performance of individual securities. In our calculations we apply the momentum returns provided by the online database of Kenneth French. The returns of MOM are based on six value-weight portfolios formed on size and prior returns of the months $t-12$ to $t-2$.

$$
\mathrm{MOM}_{t}=\frac{1}{2} \cdot(\mathrm{SHPR}+\mathrm{BHPR})-\frac{1}{2} \cdot(\mathrm{SLPR}+\mathrm{BLPR})
$$

The portfolios are the intersections of two portfolios formed on size and three portfolios formed on prior $t-12$ to $t-2$ return. SHPR, for instance, stands for Small High Prior Return. It is the intersection of small caps and stocks with a high return during the months $t-12$ to $t-2$. The monthly size breakpoint is the median NYSE market equity. The monthly prior $t-12$ to $t-2$ return breakpoints are the 30th and 70th NYSE percentiles. The portfolios are formed monthly. MOM is the average return on the two high prior return portfolios minus the average return on the two low prior return portfolios.

\section{Results of the empirical analysis}

Table 2 shows the monthly returns, averages over all business cycles, of the mentioned portfolios and the different months in relation to the peak, denominated by $t{ }^{8} \mathrm{SMB}$, for example, has a monthly (expected) return of $-1.7 \%$ in the month which is identified to be the cycle peak. Hence, in the month of a peak of business cycles, the return of small caps is approximately $1.7 \%$ below the return of large caps. One and two months before the peak month, small caps have higher returns compared to large caps (with a difference of $0.1 \%$, respectively $0.6 \%$ ).

As can be seen in the other columns of Table 2, the returns of smaller growth stocks (SL) change over the business cycle in a pronounced way. In contrast, stocks of larger neutral companies (BM) have more stable expected returns. Table 2 also shows that properties like "value" and "growth" have almost no impact on the

\footnotetext{
7 Cf. Fama and French (1993) for a detailed description of the approach.

8 Annualised expected returns are provided in the "Appendix".
} 
Table 2 Average monthly returns around economic peaks

\begin{tabular}{|c|c|c|c|c|c|c|c|c|c|c|}
\hline & $\begin{array}{l}\text { BL } \\
(\%)\end{array}$ & $\begin{array}{l}\mathrm{BM} \\
(\%)\end{array}$ & $\begin{array}{l}\mathrm{BH} \\
(\%)\end{array}$ & $\begin{array}{l}\text { SL } \\
(\%)\end{array}$ & $\begin{array}{l}\text { SM } \\
(\%)\end{array}$ & $\begin{array}{l}\mathrm{SH} \\
(\%)\end{array}$ & $\begin{array}{l}\text { MKT } \\
(\%)\end{array}$ & $\begin{array}{l}\text { SMB } \\
(\%)\end{array}$ & $\begin{array}{l}\text { HML } \\
(\%)\end{array}$ & $\begin{array}{l}\text { MOM } \\
(\%)\end{array}$ \\
\hline$t-12$ & 2.8 & $2.5^{*}$ & 2.8 & $3.0^{*}$ & 2.6 & 2.5 & $2.4^{*}$ & -0.1 & -0.3 & 0.9 \\
\hline$t-11$ & 0.8 & 1.4 & 1.9 & 1.0 & 1.5 & 2.0 & 0.8 & 0.1 & 1.0 & 0.7 \\
\hline$t-10$ & -0.1 & 0.0 & 0.8 & 1.1 & 0.5 & 0.5 & -0.4 & 0.5 & 0.1 & 1.2 \\
\hline$t-9$ & 1.6 & 1.4 & 1.1 & 0.7 & 1.1 & 1.6 & 1.2 & -0.2 & 0.2 & $2.4^{* * * *}$ \\
\hline$t-8$ & 2.6 & 2.5 & 2.7 & 2.6 & 2.1 & 2.4 & 2.2 & -0.3 & -0.1 & 1.6 \\
\hline$t-7$ & 0.4 & 1.0 & 1.5 & -0.4 & 0.5 & 0.6 & 0.4 & -0.8 & 1.0 & 1.0 \\
\hline$t-6$ & -0.7 & -1.1 & -1.0 & -0.3 & 0.0 & -0.3 & -1.2 & 0.8 & -0.2 & 1.1 \\
\hline$t-5$ & 0.8 & 0.5 & 0.2 & -0.4 & -0.3 & -0.2 & 0.2 & -0.8 & -0.2 & 1.3 \\
\hline$t-4$ & 2.4 & 1.3 & 1.1 & $4.0^{*}$ & 2.8 & 2.3 & 1.6 & 1.5 & $-1.7 * *$ & 0.2 \\
\hline$t-3$ & -0.4 & $-1.3 * *$ & -0.6 & -0.4 & $-1.5^{*}$ & $-1.9^{*}$ & -1.2 & -0.5 & -1.0 & 2.0 \\
\hline$t-2$ & 2.5 & 2.6 & $3.1^{*}$ & $3.9^{* *}$ & 3.1 & 2.9 & 2.2 & 0.6 & -0.3 & 2.0 \\
\hline$t-1$ & 0.2 & -0.6 & $-1.6^{*}$ & 0.3 & -0.7 & -1.2 & -0.5 & 0.1 & -1.9 & 2.4 \\
\hline$t$ & -1.4 & -0.5 & -2.1 & $-3.4^{* *}$ & $-2.7 * *$ & $-3.1 * *$ & -1.8 & $-1.7 * *$ & -0.3 & $3.6^{* * * *}$ \\
\hline$t+1$ & $-2.7^{* *}$ & $-1.8^{*}$ & $-2.3^{* *}$ & $-3.3^{* *}$ & $-3.4 * * *$ & $-3.0^{* * *}$ & $-2.8^{* *}$ & -1.0 & 0.3 & 1.0 \\
\hline$t+2$ & -2.0 & -1.1 & -0.8 & -2.7 & -1.5 & -1.2 & -2.0 & -0.4 & 1.3 & 0.5 \\
\hline$t+3$ & -0.5 & -0.4 & -0.2 & -1.1 & -0.2 & -0.2 & -0.8 & -0.1 & 0.6 & 0.8 \\
\hline$t+4$ & 0.5 & 0.4 & 0.3 & -1.8 & -0.4 & -0.3 & 0.0 & -1.1 & 0.6 & 0.4 \\
\hline$t+5$ & -1.4 & -1.0 & $-2.3 * *$ & -1.3 & -1.0 & -1.4 & -1.7 & 0.4 & -0.5 & 0.4 \\
\hline$t+6$ & -0.3 & -1.6 & $-2.5^{*}$ & -2.3 & -2.0 & -2.1 & -1.5 & -0.6 & -1.0 & 1.9 \\
\hline$t+7$ & 2.0 & 2.4 & 2.1 & 3.2 & 2.9 & 3.6 & 2.0 & 1.1 & 0.2 & -0.4 \\
\hline$t+8$ & 1.7 & 2.1 & 1.9 & 2.7 & $3.2^{*}$ & 3.3 & 1.6 & 1.2 & 0.4 & 0.1 \\
\hline$t+9$ & 1.7 & 1.8 & 2.1 & 3.0 & 2.9 & 2.8 & 1.4 & 1.1 & 0.0 & 0.2 \\
\hline$t+10$ & -3.2 & -2.8 & -4.9 & -4.3 & -4.0 & -4.7 & -3.6 & -0.6 & -1.0 & $4.1^{* *}$ \\
\hline$t+11$ & 3.0 & 2.3 & 2.4 & 2.4 & 2.6 & 2.2 & 2.3 & -0.1 & -0.5 & 0.7 \\
\hline$t+12$ & 0.1 & -0.1 & 0.4 & 0.4 & 0.9 & 0.9 & -0.1 & 0.6 & 0.4 & 0.4 \\
\hline
\end{tabular}

*** Significant at the $1 \%$ level, ** significant at the $5 \%$ level, * significant at the $10 \%$ level

returns around the peak of the business cycle. In the peak month, HML has an overall average return of $-0.3 \%$ which brings a phase of negative returns during the $1 \frac{1}{2}$ year before the peak to an end.

The negative returns during economic peaks may appear counterintuitive. A possible explanation is that market participants anticipate the upcoming downswing of the economy and sell securities even before the peak. ${ }^{9}$ Small Caps also underperform large caps shortly after economic peaks. This is highlighted by the negative returns of SMB between $t+1$ and $t+4$. Again, the most pronounced dip can be observed in the returns of small growth stocks (SL). During the same time window, value stocks do better than growth stocks as the returns of HML show.

\footnotetext{
9 The NBER determines the peaks and troughs after their occurrence. For instance, the peak of December 2007 was identified in December 2008. However, as the results above indicate, market participants might assess the current economic situation appropriately.
} 
With respect to SMB, the picture changes 7 months after the peak. After $t+7$ small caps often show higher returns than large caps. This development may possibly be attributed to the market participants' anticipation of the next recovery, which on average starts 13 months after the last peak. In the months before the peak, the most striking results can be observed in Table 2 for HML. Returns of HML for all months between $t-6$ and $t$ are negative with noticeable absolute values in $t-4, t-3$, and $t-1$. Hence, growth stocks outperform value stocks before economic peaks.

An interesting pattern can be observed with respect to momentum returns. The expected returns of MOM are positive throughout almost the entire 24 months around economic peaks with pronounced positive magnitudes between $t-3$ and $t$, i.e. $t+2$ when compared to the expected returns of the other portfolios. Hence, around the past 15 peaks of the US economy, winners considerably outperformed losers.

To discuss the level of significance, we apply a standard $t$-test to evaluate whether the figures given in Table 2 are significantly different from their long-term mean. The test statistic is given by (5) with sample mean $\overline{\mathrm{x}}$, mean (long-term average of returns of the respective portfolio) $\mu_{0}$, standard deviation of the sample $s$, and the number of observations (number of peaks or troughs) $n$.

$$
t=\frac{\overline{\mathrm{x}}-\mu_{0}}{s / \sqrt{n}}
$$

Values marked by asterisks indicate significance at the $1 \%(* * *), 5 \%(* *)$, or $10 \%$-level $(*)$. The return differential between small caps and large caps is significant during an economic peak: The decline in the returns of small caps is significantly stronger than the decline in the returns of large caps. Cochrane's (1999) theory according to which small caps are related to macroeconomic changes can be expressed more precisely by our observation that this relation between size and return is pronounced and concentrated around the peak months of the business cycle. This argument seems to be supported additionally by the clustering of significant negative returns of SL, SM, and SH at $t$ and $t+1 .{ }^{10}$

Now, we outline the analysis for troughs and lower turning points of the real economy. We start with the average returns and proceed then to the discussion of significance.

Table 3 exhibits the expected returns of the Fama-French Factors, their components, and MOM around troughs. Row $t$ shows the returns for the trough months. The average return of small caps is $2.1 \%$ higher than the return of large caps for trough months. The value stocks are slightly better than growth stocks. All

\footnotetext{
${ }^{10}$ The $t$-values of the components SL, SM, and SH are significant while the $t$-values for the large cap portfolios $\mathrm{BL}, \mathrm{BM}$, and $\mathrm{BH}$ are not. Consequently, during peaks, the returns of small caps deviate significantly from their long-term mean. At $t+1$, the returns of large caps also deviate significantly from their long-term mean. The return differential between value stocks and growth stocks, HML, is significant at $t-4$. Four months before an economic peak value stocks have significantly poorer returns compared to growth stocks. However, if the most extreme observation is neglected the significance vanishes. Moreover, HML is neither at $t-5$ nor at $t-3$ significant which may put the link between HML and the real economy into perspective. However, unreported values reveal a strong influence of the standard deviation of the sample on the significance of the results of HML between $t-4$ and $t$. This evidence concentrates on upper economic turning points.
} 
Table 3 Average monthly returns around economic troughs

\begin{tabular}{|c|c|c|c|c|c|c|c|c|c|c|}
\hline & $\begin{array}{l}\text { BL } \\
(\%)\end{array}$ & $\begin{array}{l}\text { BM } \\
(\%)\end{array}$ & $\begin{array}{l}\mathrm{BH} \\
(\%)\end{array}$ & $\begin{array}{l}\text { SL } \\
(\%)\end{array}$ & $\begin{array}{l}\text { SM } \\
(\%)\end{array}$ & $\begin{array}{l}\text { SH } \\
(\%)\end{array}$ & $\begin{array}{l}\text { MKT } \\
(\%)\end{array}$ & $\begin{array}{l}\text { SMB } \\
(\%)\end{array}$ & $\begin{array}{l}\text { HML } \\
(\%)\end{array}$ & $\begin{array}{l}\text { MOM } \\
(\%)\end{array}$ \\
\hline$t-12$ & -0.4 & -0.6 & -1.2 & -1.9 & -0.3 & -1.1 & -1.0 & -0.4 & -0.1 & 1.5 \\
\hline$t-11$ & -1.1 & -1.4 & -2.5 & -1.9 & -1.2 & -2.1 & -1.8 & -0.1 & -0.8 & $2.1 * *$ \\
\hline$t-10$ & -1.3 & -2.1 & -1.2 & -1.2 & -2.0 & 0.5 & -1.9 & 0.5 & 1.0 & 0.2 \\
\hline$t-9$ & $-2.2^{*}$ & -1.7 & -1.4 & -3.0 & -2.2 & -2.2 & $-2.5^{*}$ & -0.6 & 0.8 & 1.6 \\
\hline$t-8$ & -0.1 & 2.4 & 2.4 & -0.5 & 1.0 & 1.9 & 0.3 & -1.0 & 2.8 & -1.7 \\
\hline$t-7$ & 0.1 & 1.4 & 1.4 & 0.3 & 0.8 & 2.4 & 0.0 & 0.7 & 2.0 & -5.0 \\
\hline$t-6$ & -1.5 & -0.3 & -0.9 & -2.5 & -2.0 & -1.8 & -1.4 & -1.1 & 0.6 & $2.9^{* * * *}$ \\
\hline$t-5$ & -0.5 & -1.7 & $-3.2^{*}$ & -1.4 & -2.1 & -2.8 & -1.4 & -0.3 & $-2.0 * *$ & $2.7 * *$ \\
\hline$t-4$ & 0.6 & 0.2 & -0.7 & -1.1 & -0.7 & -1.4 & -0.2 & -1.0 & -0.8 & -0.3 \\
\hline$t-3$ & 0.8 & 0.9 & -0.6 & -0.7 & -0.5 & -1.4 & 0.4 & -1.1 & -1.0 & 0.8 \\
\hline$t-2$ & $4.0^{* * *}$ & 3.8 & 4.4 & 5.6 & $5.8^{*}$ & 5.4 & $3.7 * *$ & 1.8 & 0.0 & -1.3 \\
\hline$t-1$ & 2.2 & 1.8 & 0.9 & 2.9 & 2.0 & 2.4 & 1.8 & 0.9 & $-1.0^{*}$ & 0.3 \\
\hline 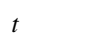 & $5.7 * * *$ & $4.8^{* * * *}$ & $6.6^{* * * *}$ & $8.1 * * *$ & $6.9^{* * *}$ & $8.1 * * *$ & $5.3 * * *$ & $2.1^{* * * *}$ & 0.4 & -1.7 \\
\hline$t+1$ & $4.6^{*}$ & 5.5 & 6.5 & $7.7^{* * *}$ & $7.6^{* *}$ & $7.8^{* * *}$ & $4.8^{*}$ & $2.4 * * *$ & 1.3 & -0.6 \\
\hline$t+2$ & $3.5^{* *}$ & 3.4 & 4.1 & 7.2 & 7.1 & 7.1 & $3.4^{*}$ & 3.9 & 0.4 & 0.1 \\
\hline$t+3$ & 2.0 & 2.3 & 2.5 & 3.6 & 4.1 & 3.3 & 1.8 & 1.5 & 0.1 & 1.3 \\
\hline$t+4$ & 2.2 & 1.8 & 1.7 & 2.6 & 2.4 & 2.4 & 1.7 & 0.6 & -0.4 & 1.1 \\
\hline$t+5$ & 1.9 & 2.7 & 2.5 & 1.7 & 2.6 & 2.2 & 1.8 & -0.2 & 0.6 & 1.1 \\
\hline$t+6$ & 0.2 & 0.0 & 0.1 & 1.5 & 0.6 & 0.0 & 0.0 & 0.6 & -0.7 & 0.8 \\
\hline$t+7$ & 0.6 & -0.2 & -1.3 & -0.5 & -0.5 & -0.5 & -0.2 & -0.2 & -0.9 & 0.7 \\
\hline$t+8$ & 0.1 & 0.1 & 0.2 & -1.9 & -0.7 & -1.2 & -0.3 & $-1.4 * *$ & 0.5 & 0.7 \\
\hline$t+9$ & 1.1 & 1.0 & 2.3 & 0.8 & 0.9 & 0.9 & 0.9 & -0.6 & 0.7 & 1.0 \\
\hline$t+10$ & 1.0 & 1.1 & 2.6 & 2.8 & 3.7 & 4.9 & 0.9 & $2.4^{* *}$ & 2.1 & 1.8 \\
\hline$t+11$ & -0.1 & 0.5 & 1.0 & -0.2 & 0.8 & 1.9 & -0.1 & 0.4 & 1.6 & -0.7 \\
\hline$t+12$ & 1.5 & 1.4 & 1.4 & 0.6 & 1.1 & 1.6 & 1.1 & -0.3 & 0.5 & -0.9 \\
\hline
\end{tabular}

*** Significant at the $1 \%$ level, ** significant at the 5\% level, * significant at the $10 \%$ level

small cap portfolios outperform their respective large cap counterpart, but there is almost no difference in the returns of small value and small growth. Hence, the positive expected value of HML is almost entirely attributable to the difference between large value and large growth. HML behaves like $\mathrm{BH}$ minus BL; the hypothesis $\mathrm{HML}=\mathrm{BH}-\mathrm{BL}$ over the business cycle cannot be rejected at $5 \%$. This says that during lows of the real economy, book-to-market characteristics are more important among large caps than among small caps.

Small caps outperform large caps already during $t-1$ and $t-2$, that is, before the lower turning point. All component portfolios as well as the aggregate market exhibit noticeable positive expected returns. The return differential between small caps and large caps is also positive in the 4 months after the trough. Particularly positive are the expected returns of SMB at $t+1$ and $t+2$. The considerable magnitude of SMB in $t+2$ stems mainly from the weakening returns of the large caps portfolios. Small caps perform slightly weaker at $t+2$ than at $t+1$ but large caps do much poorer. 
In contrast to the clustering magnitude of the returns of SMB around troughs the returns of HML and MOM do not exhibit such a pattern. HML is around zero or even negative. Hence, there is a noticeable sharp contrast in the behaviour of size sorted and book-to-market sorted portfolios before troughs. The expected returns of MOM are positive in the majority of the observed periods around troughs but exhibit negative results in times when the aggregate market performs well.

Again, the asterisks provide information on the significance of the abovepresented results. The expected returns of all market segments $\mathrm{SH}, \ldots, \mathrm{BL}$ as well as of the aggregate market MKT itself exhibit significant deviations from their longterm mean in particular around economic lows. ${ }^{11}$ This is not surprising. Most stocks may have an exposure to the real economy and they benefit when business activity accelerates.

However, we can see a significant difference between large caps and small caps. In other words, SMB, the expected return difference between small caps and large caps significantly deviates from its long-term mean at the trough and in the following month. The difference is positive and significance clusters around $t$. This indicates that small caps significantly outperform large caps especially during economic troughs.

In contrast, HML is not significant after troughs, i.e. value stocks do not do better or worse than growth stocks after troughs. Value stocks do significantly (at the $10 \%$ level) worse than growth stocks at $t-1$. Though, this is the only time close to an economic turning point when there is a significant return differential between value and growth stocks. Moreover, the significance of HML at $t-5$ vanishes if two extreme observations are neglected in the calculations. With respect to SMB, there is no significant value before the economic low.

Expected returns of MOM are significantly different to its long-term mean at $t-11, t-6$, and $t-5$. However, the significance of MOM seems to be driven by the standard deviation which fluctuates heavily. For instance, standard deviation of monthly momentum returns at $t-7$ is $19.1 \%$. The standard deviation of monthly momentum returns at $t-6$ is $2.3 \%$. This unusual low standard deviation might be the driving force behind the significance at $t-6$. Similar observations hold for $t-11$ and $t-5$. Contrary to MOM, the standard deviations of SMB at the various times around a trough seem to be more comparable. The highest standard deviation of the monthly SMB returns is $8.4 \%$ at $t+2$.

Due to the small sample the above-presented findings may be preliminary and should be interpreted with caution. Nevertheless, three observations merit a discussion. First, our evidence supports the hypothesis that SMB is linked to the real economy. In particular, SMB exhibits significant deviations from its long-term mean at and around upper and lower economic turning points. Second, the evidence on a relationship between HML and certain phases of the real economy is weaker which raises the question of other possible risk sources or alternative interpretations. This seems to be an important point as the risk premium for HML is usually higher than the risk premium for SMB. Third, momentum returns seem unusually high between $t-3$ and economic peaks.

\footnotetext{
${ }^{11}$ Unreported results show that the $t$-values are somewhat stronger and more concentrated for troughs than the values for peaks.
} 


\section{SMB, HML, and MOM as proxies for macroeconomic risks?}

The negative returns of SMB around peaks underline the poor returns of small caps during upper economic turning points. The significant positive returns of SMB which cluster around troughs show a stronger performance of small caps when economic activity is low. Hence, SMB possibly reflects macroeconomic risks which are associated with economic highs and lows, i.e. particular phases of the business cycle. Regarding the covariance between phases of the business cycle, Spremann and Scheurle (2009) argue that small caps strongly benefit if business activity accelerates after a recession. While the profits of small caps may jump during an improving economy the profits of large caps may show a somewhat more moderate development. A major reason for this difference is the level of diversification with respect to not perfectly correlated business activities. The prospects of a small cap might be much brighter as the real economy starts to improve. The opposite is true if the real economy is full of verve and might decline or glide into recession. One reason for the revealed cyclical pattern of "size" could be the pro-cyclical impulses of the credit market (Perez-Quiros and Timmermann 2000). Credit markets are tight during recessions, which could penalize small firms compared to bigger companies. For instance, small companies may be more dependent on bank loans than large companies who have access to debt markets. Hence, in a recession, when banks may be reluctant to provide companies with liquidity, smaller companies may face serious challenges as they run out of liquidity. The credit crisis of 2008 and 2009 may be a good example with respect to tight credit markets and its impact on smaller companies.

Value stocks have a high book-to-market ratio, i.e. the book value of those stocks is only slightly lower or even higher than their market value. Hence, investors do not recognise assets like brand names which are important for the success of a company but which are not allowed to activate on the balance sheet. In other words, value stocks are valued around their net asset value or breakup value.

Such companies may be regarded as "dogs", as firms with a need for reorganisation. The management will have to take action in order to avoid bankruptcy and increase market value. However, value companies find themselves in a fragile situation. A reorganisation project locks resources and the management's focus may be on the company itself rather than on the environment. Though, the best reorganisation plan may fail if the environment is not supportive. For instance, a (further) dip of the real economy might be sufficient to cause bankruptcy. Therefore, value stocks may react to an upcoming economic downturn well in advance. The above-presented evidence supports this argument.

The returns of HML differ significantly from their long-term mean on average 4 months before an economic peak which is 4 months before the significant negative reaction of SMB. Moreover, HML is negative as of $t-6$ until the peak. The evidence seems less clear for times around troughs. However, the returns of HML appear to stabilise somewhat earlier than the returns of SMB but lack to show significant positive returns in the aftermath of a lower economic turning point. In addition, the return differential between $\mathrm{BH}$ and $\mathrm{BL}$ is often positive and considerably higher than the difference between SH and SL, i.e. investors differentiate whether a company is large and distressed or small and distressed. 
In turn, most investors might be reluctant to buy or hold stocks which strongly depend on the real economy in times when their personal income is at risk. However, as it becomes more and more apparent that business activity accelerates or continues to increase, small caps and value stocks deliver high returns as prices are bid up. Those who invested early can realize considerable returns.

The above-presented risk-story for SMB and HML is supported by research such as Cochrane (1999) or Liew and Vassalou (2000). Nevertheless, the riskinterpretation can be challenged. There might be other explanations for the significant positive and negative returns of SMB and HML around economic turning points. For instance, the high premia of some market segments during particular phases of the business cycle could be attributable to speculative motives or taste.

Before troughs, investors bet on large growth stocks and from $t-2$ on small value stocks offer considerable excess returns. Before peaks, when the economy is booming, many investors may find (small) growth stocks especially attractive, driving up their prices. Later, large value stocks may be more attractive, for what so ever reason, and investors heavily buy those shares. Thus, the returns on SMB and HML might give information about rewarding investment strategies but not necessarily on risk premia associated with the business cycle.

The interpretation of MOM might be different in some ways to SMB and HML. Surprisingly, expected momentum returns are positive in the majority of the observed phases of the business cycle. Though, from time to time, expected momentum returns show opposite signs compared to the aggregate market or the market segments $\mathrm{SH}, \ldots, \mathrm{BL}$. For instance, at peaks, when the broad market goes down, MOM is significantly positive. And at troughs, when MKT is significantly positive, MOM is negative. MOM might mimic for particular risks as well. Conrad and Kaul (1998), for instance, outline the possibility that momentum profits might be attributable to cross-sectional differences in risk, i.e. in expected returns. However, it does not seem that the high premia of momentum strategies compensate for risks associated to specific phases of the business cycle.

Evidence such as provided in Jegadeesh and Titman (2001) contradicts with the arguments of Conrad and Kaul (1998) and supports behavioral explanations. Our results could favor a behavioral explanation as well. MOM returns are, on average, high between $t-3$ and 1 month after economic peaks. This might be a period when everybody (especially the media) is enthusiastic about the economy and stock markets. In turn, many naïve investors might be attracted who buy the most recent winners. Thus, if it is finally proven that momentum returns are for real, then a behavioural explanation could apply. ${ }^{12}$

\section{Conclusion}

One result seems to be striking. The magnitude and significance of the return differential between small caps and large caps clusters in particular around

\footnotetext{
${ }^{12}$ Fama and French (1996) or Cochrane (2005, pp. 21-23) question if the momentum effect is real or whether it may be attributed to statistical issues.
} 
economic troughs. In other words: Despite the fact that all market segments $\mathrm{SH}, \ldots, \mathrm{BL}$ as well as the aggregate Market MKT exhibit significant positive returns, there remains a significant difference between small caps and large caps around economic lows. This result is robust to outliers. However, we acknowledge the small sample size and the related question if this preliminary evidence will stand the test of time. Moreover, the clustering might be associated to risks as well as to behavioral aspects. However, with the theoretical foundation of Cochrane (1999) and earlier empirical evidence such as Liew and Vassalou (2000) in view, we offer a risk-based interpretation of the risk premia-in particular the one of SMB.

An engagement in "small size" rewards for the risks associated with the early upswing: SMB may represent the uncertainty regarding the timing of the beginning of a new cycle, i.e. mimics risks related to early phases of an economic upswing. The return of SMB becomes much higher when the real economy bottoms out and during the months thereafter. But SMB is definitively at a lower level later, that is, during the growth and peak period, and after the peak of the business cycle. Hence, small size rewards early birds who take the risk to invest when the fresh upswing could start but is not yet visible. The timing of the literal silver lining is definitively risky: The flaring light could deceive, economic activity could fall back into recession.

The results on the return differential between value stocks and growth stocks are less evident than for SMB. This seems interesting as the premium for HML is in many markets higher than the premium for SMB. With respect to the real economy, HML is considerably positive, but not significant, well before peaks and well before or well after a trough, i.e. in more mature phases of the business cycle. Hence, despite the lacking significance, a risk-based explanation might hold for HML as well.

"Value" (or as we have seen "big value") could reward for the risks associated with the uncertainty in the next phase, which starts after the trough, of a business cycle when it hopefully gains and becomes full of verve. The risk is whether economic activity continues to grow or lashes back. HML might mimic this danger of a short expansion and an early down-turn. In this phase, when "small size" is already cooling down, HML bears its premium. Investors who stay then in "big value" will be rewarded for their courage to bet on enlargement and extension (which clearly begins to benefit industrials, i.e. large and diversified corporations). If the cycle continues, HML shows high returns. After that phase of upswing, around the peak and when the possibility of saturation and cooling down becomes apparent, returns of HML become negative.

Consequently, small and value may capture two uncertainties: SMB: Will the silver lining lead to an upswing or not? HML: Will the loose forces in the upswing continue and gain broadness and firmness (or not)? Both uncertainties are unwanted risks for most investors because they already have an exposure in the real economy. But a few investors can more easily bear the risks associated with an upswing after a trough, while others might be willing to bear the risks which are typical for the next phase in the business cycle. Accordingly, these few investors should either focus on assets with a strong beta in size or a strong exposure with respect to value. The majority of investors, however, should become aware that additional premia in the 
stock market could easily be the compensation for the particular risks during the phases of a beginning and a continuing business cycle.

Contrary to SMB and HML we do not see a risk-based interpretation which could explain the high excess returns of MOM. Expected returns of MOM are significantly positive at peaks and of considerable magnitude the 3 months before the peak. This might be a period when we all are confident about the real economy and stock markets. In turn, the overwhelmingly positive news could attract many naïve investors who buy the most recent winners. Hence, if the high momentum returns are for real, then we could imagine a behavioural explanation. Meanwhile, the momentum effect remains a puzzling anomaly to us and may remain a fruitful ground for further research.

\section{Appendix}

See Tables 4, 5.

Table 4 Annualised means around economic peaks

\begin{tabular}{|c|c|c|c|c|c|c|c|c|c|c|}
\hline & $\begin{array}{l}\text { BL } \\
(\%)\end{array}$ & $\begin{array}{l}\text { BM } \\
(\%)\end{array}$ & $\begin{array}{l}\text { BH } \\
(\%)\end{array}$ & $\begin{array}{l}\text { SL } \\
(\%)\end{array}$ & $\begin{array}{l}\text { SM } \\
(\%)\end{array}$ & $\begin{array}{l}\mathrm{SH} \\
(\%)\end{array}$ & $\begin{array}{l}\text { MKT } \\
(\%)\end{array}$ & $\begin{array}{l}\text { SMB } \\
(\%)\end{array}$ & $\begin{array}{l}\text { HML } \\
(\%)\end{array}$ & $\begin{array}{l}\text { MOM } \\
(\%)\end{array}$ \\
\hline$t-12$ & 33.9 & $30.0 *$ & 34.0 & $35.8 *$ & 30.6 & 30.5 & $28.6^{*}$ & -0.8 & -3.3 & 10.2 \\
\hline$t-11$ & 10.1 & 16.5 & 23.2 & 12.0 & 18.3 & 23.8 & 9.0 & 1.3 & 12.5 & 7.8 \\
\hline$t-10$ & -1.6 & 0.0 & 9.1 & 13.1 & 5.8 & 6.2 & -5.0 & 6.3 & 1.4 & 14.4 \\
\hline$t-9$ & 19.5 & 16.5 & 13.6 & 8.6 & 13.4 & 18.8 & 13.9 & -2.6 & 2.0 & $28.8 * * *$ \\
\hline$t-8$ & 31.1 & 29.9 & 32.2 & 31.0 & 25.1 & 28.2 & 26.1 & -3.2 & -1.4 & 19.4 \\
\hline$t-7$ & 4.7 & 12.2 & 17.8 & -5.3 & 5.8 & 7.6 & 4.3 & -9.1 & 12.5 & 12.0 \\
\hline$t-6$ & -8.1 & -13.2 & -12.3 & -4.1 & 0.3 & -3.2 & -14.3 & 9.4 & -2.2 & 12.9 \\
\hline$t-5$ & 9.7 & 6.1 & 2.9 & -5.3 & -3.7 & -2.7 & 2.6 & -9.9 & -2.6 & 16.2 \\
\hline$t-4$ & 28.7 & 15.0 & 12.8 & $48.3 *$ & 33.2 & 27.2 & 19.4 & 18.0 & $-20.3^{* *}$ & 2.3 \\
\hline$t-3$ & -4.8 & $-15.9 * *$ & -7.2 & -4.6 & $-18.2 *$ & $-22.4 *$ & -14.3 & -5.4 & -11.9 & 23.7 \\
\hline$t-2$ & 30.0 & 31.7 & $37.7 *$ & $47.3 * *$ & 36.9 & 35.1 & 26.2 & 6.7 & -3.3 & 23.9 \\
\hline$t-1$ & 2.1 & -7.2 & $-19.6^{*}$ & 3.2 & -8.4 & -14.9 & -5.6 & 1.7 & -22.8 & 28.4 \\
\hline$t$ & -16.6 & -5.8 & -25.6 & $-41.2 * *$ & $-32.6^{* *}$ & $-37.7 * *$ & -21.7 & $-20.6^{* *}$ & -3.2 & $43.6^{* * * *}$ \\
\hline$t+1$ & $-32.8 * *$ & $-21.4 *$ & $-27.6^{* *}$ & $-40.2 * *$ & $-40.7 * * *$ & $-36.3 * * *$ & $-33.1 * *$ & -11.5 & 3.1 & 11.8 \\
\hline$t+2$ & -24.4 & -12.9 & -9.1 & -32.8 & -17.6 & -14.7 & -24.5 & -4.6 & 15.1 & 5.8 \\
\hline$t+3$ & -6.5 & -5.2 & -2.1 & -13.3 & -2.1 & -2.0 & -9.8 & -1.1 & 6.8 & 9.9 \\
\hline$t+4$ & 5.9 & 4.4 & 3.6 & -21.5 & -5.2 & -4.1 & -0.1 & -13.3 & 7.1 & 4.4 \\
\hline$t+5$ & -16.7 & -12.3 & $-28.0 * *$ & -16.2 & -11.5 & -16.9 & -20.6 & 4.6 & -6.5 & 5.0 \\
\hline$t+6$ & -3.3 & -19.2 & $-30.4^{*}$ & -28.0 & -24.4 & -24.9 & -17.6 & -6.8 & -12.3 & 23.1 \\
\hline$t+7$ & 24.2 & 28.7 & 25.4 & 38.1 & 34.6 & 43.1 & 24.4 & 13.4 & 2.6 & -4.8 \\
\hline$t+8$ & 20.9 & 25.0 & 22.6 & 31.9 & $38.1 *$ & 40.2 & 19.4 & 14.1 & 4.7 & 1.3 \\
\hline$t+9$ & 20.6 & 21.3 & 25.2 & 36.2 & 35.4 & 33.1 & 17.0 & 12.9 & -0.4 & 2.9 \\
\hline$t+10$ & -37.9 & -33.5 & -58.9 & -51.5 & -47.7 & -56.7 & -43.7 & -6.9 & -12.2 & $49.2 * * *$ \\
\hline$t+11$ & 36.1 & 27.4 & 28.2 & 28.5 & 31.0 & 26.9 & 28.1 & -1.1 & -6.0 & 8.8 \\
\hline$t+12$ & 0.8 & -1.2 & 4.8 & 5.0 & 10.5 & 11.0 & -1.7 & 7.7 & 5.1 & 4.7 \\
\hline
\end{tabular}

*** Significant at the $1 \%$ level, ** significant at the $5 \%$ level, * significant at the $10 \%$ level 


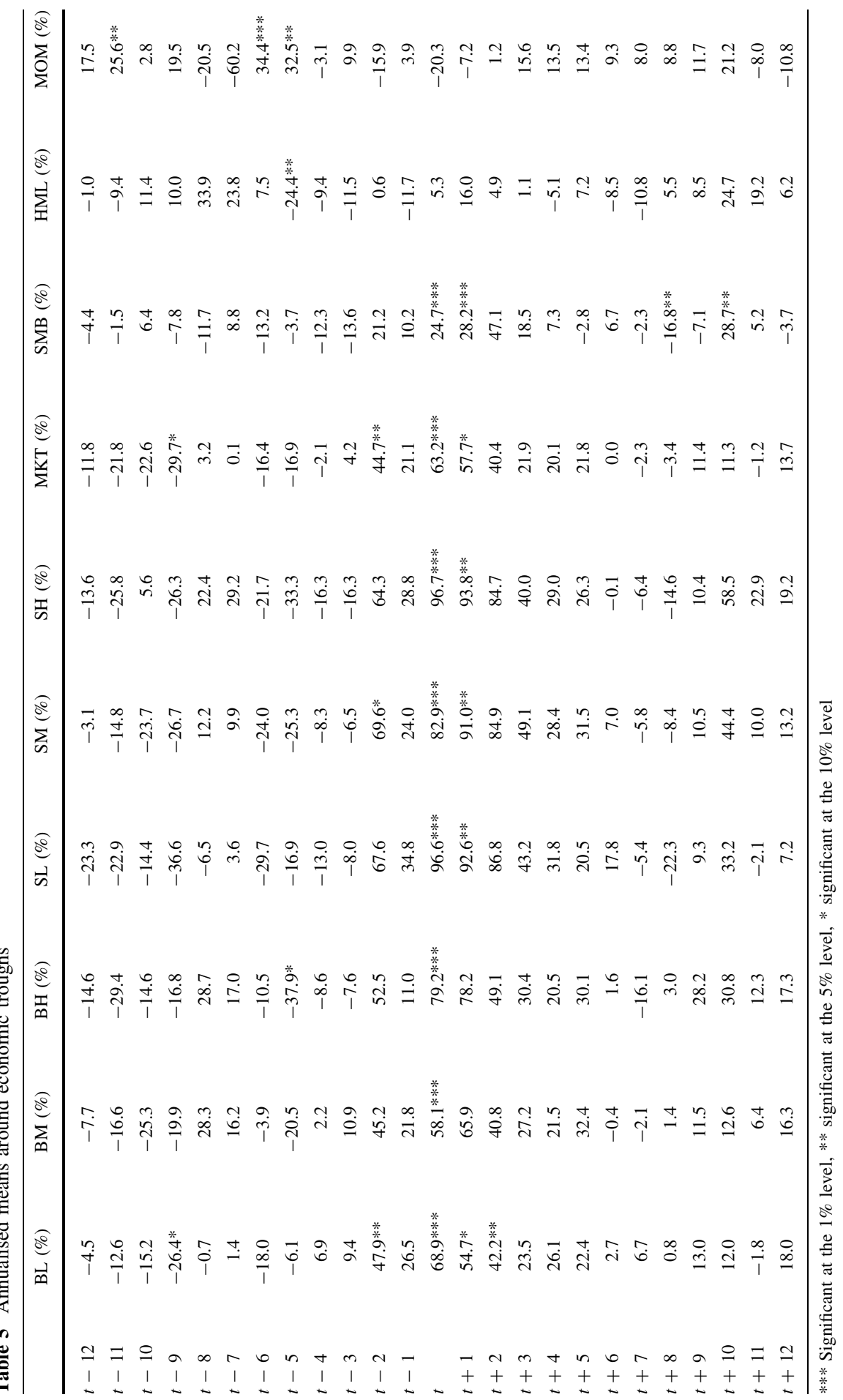

\section{䈝 Springer}




\section{References}

Amihud Y (2002) Illiquidity and stock returns: cross-section and time-series effects. J Financ Mark $5: 31-56$

Banz RW (1981) The relationship between return and market value of common stocks. J Financ Econ 9:3-18

Barro RJ (2005) Rare events and the equity premium, NBER working paper no. W11310

Basu S (1977) Investment performance of common stocks in relation to their price-earnings ratios: a test of the efficient market hypothesis. J Financ 32:663-682

Basu S (1983) The relationship between earnings' yield, market value and return for NYSE common stocks: further evidence. J Financ Econ 12:129-156

Bessler W, Opfer H (2003) Eine empirische Untersuchung zur Bedeutung makroökonomischer Einflussfaktoren auf Aktienrenditen am deutschen Kapitalmarkt. Financ Mark Portf Manag 4:412-436

Carhart M (1997) On persistence in mutual fund performance. J Financ 52:57-82

Chen N, Zhang F (1998) Risk and return of value stocks. J Bus 71:501-535

Chen N, Roll R, Ross S (1986) Economic forces and the stock market. J Bus 59:383-403

Cochrane J (1999) New facts in finance, economic perspectives 23, Federal Reserve Bank of Chicago, pp 36-58

Cochrane J (2005) Financial markets and the real economy. Now, Hanover, MA

Conrad J, Kaul G (1998) An anatomy of trading strategies. Rev Financ Stud 11:489-519

Fama E, French K (1993) Common risk factors in the returns on stocks and bonds. J Financ Econ 33:3-56

Fama E, French K (1996) Multifactor explanations of asset pricing anomalies. J Financ 51:55-84

Fama E, French K (1998) Value versus growth: the international evidence. J Financ 53:1975-1999

Fama E, French K (2006) The value premium and the CAPM. J Financ 61:2163-2184

Griffin JM (2002) Are the fama and French factors global or country specific? Rev Financ Stud 15:783-803

Jegadeesh N, Titman S (1993) Returns to buying winners and selling losers: implications for stock market efficiency. J Financ 48:65-91

Jegadeesh N, Titman S (2001) Profitability of momentum strategies: an evaluation of alternative explanations. J Financ 56:699-720

Liew J, Vassalou M (2000) Can book-to-market, size and momentum be risk factors that predict economic growth? J Financ Econ 57:221-245

Mehra R, Prescott EC (1988) The equity risk premium: a solution? J Monet Econ 22:133-136

Perez-Quiros G, Timmermann A (2000) Firm size and cyclical variations in stock returns. J Financ 55:1229-1262

Reinganum MR (1981) Misspecification of capital asset pricing: empirical anomalies based on earnings' yields and market values. J Financ Econ 9:19-46

Rietz TA (1988) The equity premium: a solution. J Monet Econ 22:117-131

Roll R (1981) A possible explanation of the small firm effect. J Financ 36:879-888

Sharpe WF (1963) A simplified model for portfolio analysis. Manage Sci 9:277-293

Spremann K, Scheurle P (2009) Kapitalkosten bei zyklischen Risiken. In: Seicht G (ed) Jahrbuch für Controlling und Rechnungswesen. Wien, pp 361-382 